\title{
How THE CORPUS IS ARRANGED
}

This corpus transcribes, translates and annotates every masoretic note in the Leningrad Codex that accompanies the text of the six books of the Former Prophets (Joshua, Judges, 1 Samuel, 2 Samuel, 1 Kings, and 2 Kings). The following sample entry of the lemma וַיְביאִהּו (Judg 1:7) will serve to illustrate how the corpus is arranged. First we present the entry as it occurs in the corpus, and then describe each section of this entry in more detail.

\section{Judges 1:7}

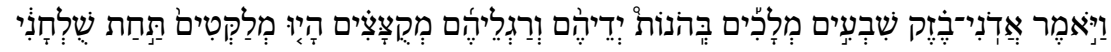

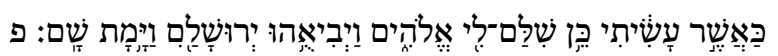

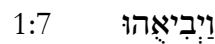

Seven times $\quad$ i $\mathrm{Mp}$

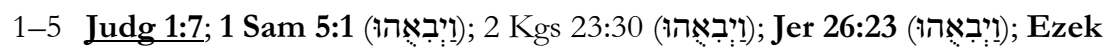

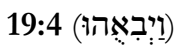

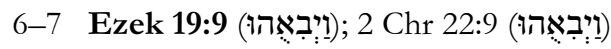

\begin{tabular}{|c|c|c|}
\hline יאֶֶהוּ & וַיְב seven times & (ויבאהו) [ויביאהו] ז \\
\hline $1-5$ & Judg 1:7 & אדני בזק \\
\hline & 1 Sam 5:1 & ופלשתים \\
\hline & $<$ Ezek 19:4> & \\
\hline & Ezek 19:9 & בסוגר \\
\hline & $\{$ Ezek 19:8\} & \{ממדינות\} \\
\hline & $2 \mathrm{Kgs} 23: 30$ & וירכבהו \\
\hline $6-7$ & 2 Chr 22:9 & אחזיהו \\
\hline & Jer 26:23 & אוריהו \\
\hline
\end{tabular}


Com:: The Masorah notes the seven occurrences of this lemma, written plene and

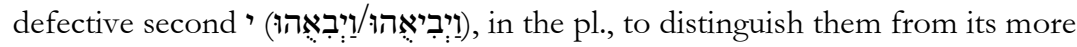
numerous occurrences $(13 \mathrm{x})$, written plene and defective second ', in the sg.

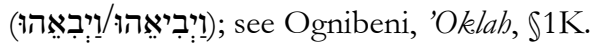

All the highlighted Mp notes read seven times except for the one at 1 Sam 5:1, which reads six times defective (second') because it does not include the form here

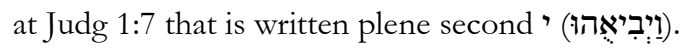

In the $\mathrm{Mm}$, in place of a catchword for the Ezek 19:4 reference, a catchword מִמְּדִינוֹת from Ezek 19:8 has mistakenly been written.

Depending on what is in the ms., each entry may consist of the following: (1) its lemma (2) a Masorah parva (Mp) note; (3) references for the Mp note; (4) a Masorah magna (Mm) note; (5) catchwords and references for the Mm note; (6) a commentary; and (7) textual notes.

1. The lemma. The lemma entry consists of the chapter and verse number (here, 1:7) of the respective book and the form of the word or words (= the lemma) as it appears in the text of $\mathrm{M}^{\mathrm{L}}$.

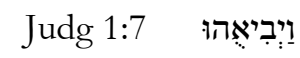

The verse numbers correspond to the standard enumeration of the various chapters as presented in the editions of BHS or BHL. ${ }^{1}$ The lemma is always presented with its vowels, as it is written in the text of $\mathrm{M}^{\mathrm{L}}$ and, where germane for the understanding of a note, the lemma is provided with accentuation. ${ }^{2}$

2. The Masorah parva (Mp) note. The Masorah parva note consists of three elements. Firstly, on the right hand side is an indication that the note is a Masorah parva (Mp) one, and not a Masorah magna note (Mm).

$$
\text { Seven times } \quad \text { i } \mathrm{Mp}
$$

Secondly, this $\mathrm{Mp}$ indication is followed by the masoretic note as it appears in the ms. (here $\dot{i}$ ). Thirdly, in the left hand margin is the translation of the note (here "seven times").

3. The references for the $\mathrm{Mp}$ note. The references for the Mp note are arranged chronologically according to the order of the traditional canonical books (e.g., To-

${ }^{1}$ Occasionally the verse numbers will vary in different printed editions. For example, at Joshua 21 the enumeration in BHS includes two verses (36 and 37), which are not in the editions of Mikra'ot Gedolot 'Haketer' or Breuer, Torah Neviim Ketuvim.

${ }^{2}$ Especially in cases where the note is concerned with words accented mil' $\hat{e} l$ (on the penultimate) or milra' (the ultimate). 
rah, Prophets, and Writings). The main difference between this traditional order and that of $\mathrm{M}^{\mathrm{L}}$ is in the order of the Writings. The traditional order lists Psalms, Proverbs, Job, etc. with Chronicles at the end, whereas the Codex places Job before Proverbs, and Chronicles before Psalms.

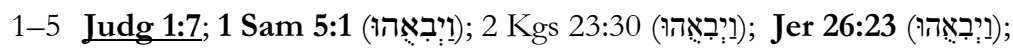

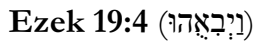

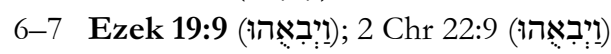

Where the lemma has Mp notes elsewhere in the ms, those references are indicated in bold type. In the above example, in addition to Judg 1:7, the references that are indicated in bold type are 1 Sam 5:1; Jer 26:23; Ezek 19:4 and 19:9, and all these have $\mathrm{Mp}$ notes at their respective occurrences in $\mathrm{M}^{\mathrm{L}}$.

Unless it is so indicated in the commentary, it can be assumed that the notes at these occurrences are exactly the same as the note in the lemma under discussion. In this case, all the highlighted Mp notes read "seven times" except that at 1 Sam 5:1, which reads "six times defective." The difference between the note headings is explained in the commentary.

Where the form of the lemma varies in the other references, the vocalization of those other references is given in parentheses. Here the vocalization of all the forms other than that at Judg 1:7 differs, so the vocalization of these forms is given in parentheses following their specific references. It will be seen that all forms, other than

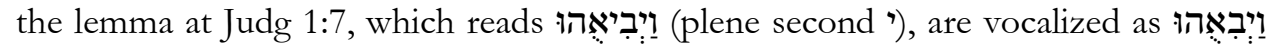
(defective second').

Where a $\mathrm{Mp}$ also has a Mm note, that fact is indicated by underlining. In the above example, the only $\mathrm{Mp}$ that has a Mm note is the one at Judg 1:7 and so that reference is indicated both by bold type (because it has a Mp note), and by underlining (because it has a Mm note).

For clarity of reading the references are bunched in groups of five, and preceded by Arabic numerals (1-5).

4. The Masorah magna (Mm) note. The lemma heading is always introduced by the siglum $\mathrm{Mm}$ on the right hand side to indicate that the note is a Masorah magna note $(\mathrm{Mm})$ rather than a Masorah parva note $(\mathrm{Mp})$ :

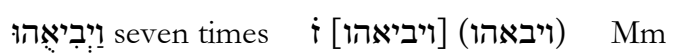

The Mm heading is reproduced exactly as it is written in the ms. Where a lemma heading differs from the text of $\mathrm{M}^{\mathrm{L}}$ lemma that heading is placed in parentheses and is followed by the text of the ms. in square brackets. ${ }^{3}$ In this example from Judg 7:1

${ }^{3}$ This method will allow future researchers to investigate whether or not the text of the Masorah represents a different source. Examples of possible preservations of alternate textual readings in a Masorah note are (1) at Judg 9:6 (אלון) in the catchwords given for 1 


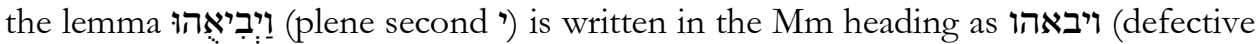
second '). Since the lemma heading differs from the text of $\mathrm{M}^{\mathrm{L}}$, which is heading is placed in parentheses (ויבאהו), and the form that occurs in the text of $\mathrm{M}^{\mathrm{L}}$ is placed immediately afterwards in square brackets [ויביאהו]. The Mm form is presented unpointed since all Hebrew words in the Mm are unpointed. Only in exceptional cases are vowels or accents given in the Mm. ${ }^{4}$

The lemma heading is immediately followed by the masoretic note as it appears in the ms. (here $\mathbf{i}$ ). On the left hand side the lemma, that is given in the Mm unvocalized (ויביאהו), is vocalized (ויְביביאהוּ) together with a translation of the note ("seven times").

5. The catchwords and references for the $\mathbf{M m}$ note. The $\mathrm{Mm}$ gives the references to the biblical verses by means of simanim or catchwords. These catchwords represent one or more words from the verse that is being referred to. There is no fixed formula for the selection of catchwords from a verse although there is a tendency for catchwords to be either at the beginning of a verse or close to the lemma that is in the verse. ${ }^{5}$ When Mm notes are repeated, catchwords from different parts of a verse are often used. ${ }^{6}$

The Mm catchwords and their references are both lined up vertically so that one can immediately match the catchwords with their appropriate verse listed in the same horizontal line.

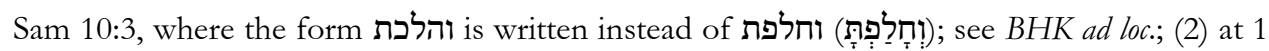

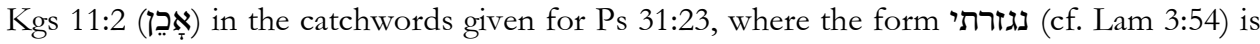

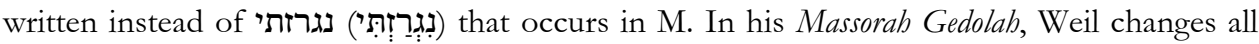
these differences to the reading of $\mathrm{M}^{\mathrm{L}}$ by means of asterisks so there there is no way that a reader can tell what was in the orginal note. On this point, see also Loewinger, "Review," 603-04.

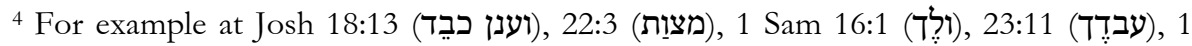

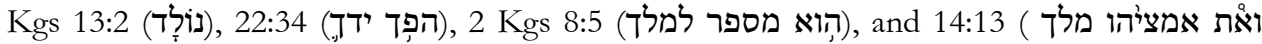
יהודה).

${ }^{5}$ In our study of doublet catchwords we found that these catchwords tend to be contiguous, and either follow or precede the doublet they illustrate; see Marcus, "Doublet Catchwords," \$6.

${ }^{6}$ See for example the different catchwords in the two Mm notes at Judg 5:30 (רחָם), at 2 Sam 15:27 (הֶרוֹאֶה); etc. 
The References

1-5 Judg 1:7

1 Sam 5:1

$<$ Ezek 19:4>

Ezek 19:9

\{Ezek 19:8\}

2 Kgs 23:30

6-7 2 Chr 22:9

Jer 26:23

\author{
The Catchwords \\ אדני בזק \\ ופלשתים \\ בסוגר \\ \{ממדינות \\ וירכבהו \\ אחזיהו \\ אוריהו - אחיהו
}

The catchwords generally conform to the way the catchwords appear in their appropriate passages in $\mathrm{M}^{\mathrm{L}}$. However, occasionally catchwords are written incorrectly, abbreviated, or omitted altogether, and sometimes extraneous words appear which do not belong to the context.

Where the catchwords differ from the text of $\mathrm{M}^{\mathrm{L}}$ or are written in an abbreviated fashion, the form found in the Masorah is placed in parentheses and the form that appears in the text of $\mathrm{M}^{\mathrm{L}}$ follows in square brackets. Where a catchword has been omitted from the list the reference is included in angle brackets. In the example above no catchword has been included in the Mm list for Ezek 19:4 so the reference is supplied in angle brackets (<Ezek 19:4>). Where extraneous material appears in a reference this extraneous material is highlighted in situ by means of curly brackets or braces $\{\ldots\}$. Thus in the example above, the catchword מְִִּדינוֹת from Ezek 19:8, which has mistakenly been written in this Mm note is placed in curly brackets.

This work always replicates the catchwords in the order in which they appear in the masoretic note. It will be noticed in this example that the references are not in the standard chronological biblical order. Here the references for both sets of catchwords from Ezekiel have been placed before the catchwords for $2 \mathrm{Kgs}$ 23:30, and the catchword for $2 \mathrm{Chr} 22: 9$ has been placed before that of Jer 26:23.

All references that have $\mathrm{Mm}$ entries are indicated by being underlined. In the above example the only reference that is underlined is the one at Judg 1:7 but it is not uncommon, as will be seen throughout the work, for numerous references to have $\mathrm{Mm}$ notes.

6. The commentary. The commentary, which is always introduced by the designation Com: in the left hand margin, offers a possible explanation for the note, indicates any problems with the note, or may simply refer the reader to the first time that this note was encountered. The commentary will usually observe that occurrences of the lemma are to be distinguished from occurrences of another similar or contrasting form. If the number of those other occurrences are two or just one, the actual biblical references are indicated. But when the number of the other occurrences are three or more, then the biblical references are not given, only an indication of the number of such occurrences in Arabic numerals followed by an x. (e.g., $6 \mathrm{x}=$ six times). Very large numbers in the hundreds are simply indicated by $100+$ or $200+$ etc. 
Com: The Masorah notes the seven occurrences of this lemma, written plene

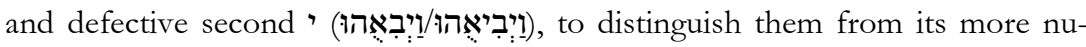
merous occurrences (13x), written plene and defective second ', in the sg.

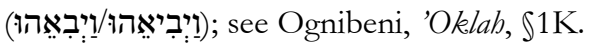

All the highlighted Mp notes read seven times except for the one at 1 Sam 5:1, which reads six times defective (second') because it does not include the form here at Judg 1:7 that is written plene second (ויבְיבְיאהוּוֹ).

In the Mm, in place of a catchword for the Ezek 19:4 reference, a catchword מִמְּדִינוֹת from Ezek 19:8 has mistakenly been written.

In the above example from Judg 1:7, the Masorah notes the seven occurrences of

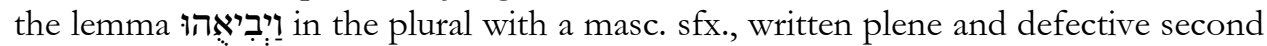

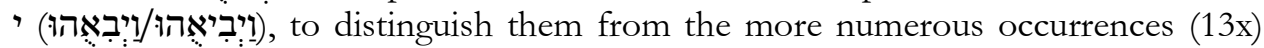
of this lemma, written plene and defective second', in the sg. with masc. sfx.

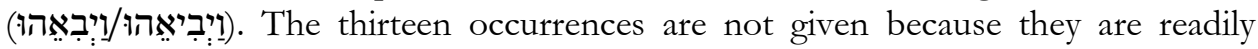
available in standard printed concordances or electronic search programs.

The commentary is the place where divergent $\mathrm{Mp}$ headings are noted. In the above example, the Mp heading at 1 Sam 5:1 reads "six times defective," whereas all the other Mp notes highlighted in the note read "seven times." The commentary observes that the 1 Sam 5:1 heading can be explained because that heading "six times defective" is only taking into account forms of this lemma that occurs written

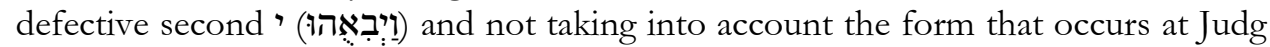
1:7, which is written plene second (ויביביאִהוּ). However, all the other headings, including the one at Judg 1:7, that read "seven times" are taking into account forms

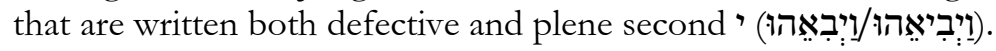

The commentary is also the place where any problem with the catchwords or references are noted. Thus in the above example, a note is made about the fact that מִ מִמִדינוֹת from Ezek 19:8 has mistakenly been written.

7. Textual notes. The textual notes appearing after the commentary section deal with matters pertaining to the text of the manuscript as far as the masoretic notes are concerned. Thus they deal with the circelli, the small circles that are on top of a word or phrase, and comment on their absence or misplacement particularly whether a lemma needs to be shortened or lengthened. These notes also deal with the placement of the Mm notes if they do not occur on the same folio as the text of the lemma, and notes whether they occur on the preceding or following folio.

\section{TEXTUAL NOTES CONCERNING THE MP}

The types of notes given in these textual notes concerning the Mp are indicated below.

- Circellus but no note. These are cases where a lemma has a circellus placed over the word or phrase, but there is no corresponding note; see at Judg 6:12

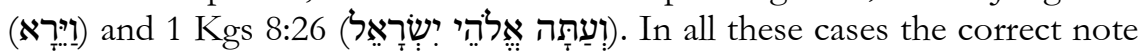
can be correctly surmised. 
- Note but no circellus. These are cases where a lemma has a note, but there is no circellus placed over the accompanying word or phrase; see at Josh 10:26

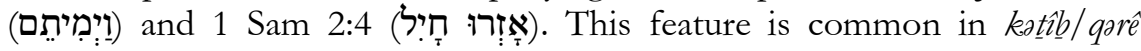

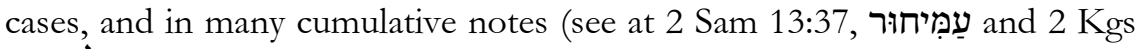
$6: 11$, עַ).

- One circellus but two notes. These are cases where only one circellus has been placed on a lemma, but two notes are given. This occurs most frequently with kațîb/qarê notes (see at 2 Sam 22:15 (דברְריך), and many times in these cases one note is placed on the left side of the column and the second Mp note is placed on the right side.

- Two circelli on one word. These are cases where two circelli have been placed on a lemma but only one note is given; see at Josh 2:3 (הוֹצִיאיִ) and Judg 11:25 (נִלְח).

- Circellus placed on first word in verse. This feature is particularly common with cumulative or collative type notes such as sequences of prepositions

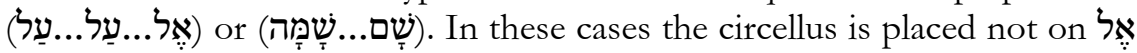
or שָׁ, but on the first word in the verse in which these sequences occur; see 1 Sam 15:1 (אָ) and 2 Kgs 4:10 (שָָ).

- Only two circelli given for large phrases. With four-five- or six-word phrases it is not unusual for only two circelli to be given. For example, on the phrase

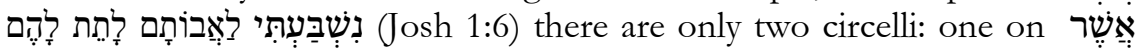

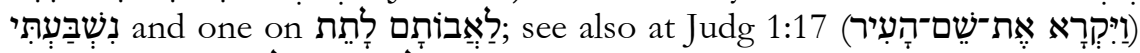

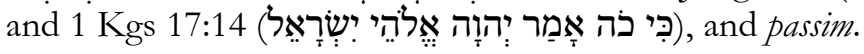

- Misplaced circellus. Occasionally the circellus has been misplaced in the manuscript. Instead of being on the lemma appropriate to the accompanying note, it has been placed on the preceding or following word. For example, at Judg 17:1 the circellus has mistakenly been placed on the

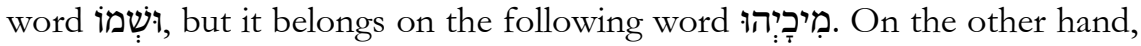
at Judg 19:22, the circellus has been placed on the word מֵיטִיכיבים instead of on the preceding one הָָָּ.

- Notes on the wrong side of the column. Normally the Mp note is placed either in the left or right side of the column directly adjacent to its text. However, occasionally the note is placed in the wrong margin. Thus at 2 Sam 12:12,

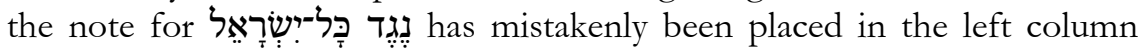
instead of the right column and, similarly, the note for וֶנֶֶ has mistakenly been placed in the right column instead of in the left one.

- Lemma needs to be extended. Occasionally, as is clear from parallel occurrences in $\mathrm{M}^{\mathrm{L}}$ or from other mss., a lemma needs to be extended because it does not meet the requirements of the note. At Josh 1:14 there is a circellus on the word הַחיל a note that states "five times with a patah." But the form הַחַי occurs fourteen times, so it is most likely, as is correctly indicated in $\mathrm{M}^{\mathrm{A}}$ and in the $\mathrm{Mp}$ notes of $\mathrm{M}^{\mathrm{L}}$ elsewhere, that the note should also include

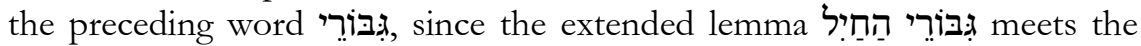
requirements of the note occuring five times with a patah. Similarly, at 1 Sam 


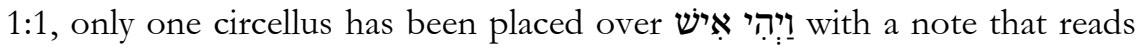
"twice." But that phrase occurs eight times so it is most likely that, with MC

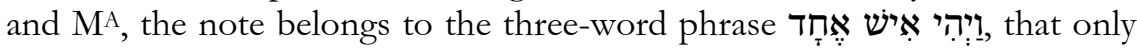
occurs twice.

- Lemma needs to be shortened. A similar situation involves cases where the lemma needs to be shortened. At Judg 19:9 a circellus has been placed on the two words לְעְרב לִינו with a corresponding note of "twice." But, since this phrase only occurs once, it is most likely that, with $\mathrm{M}^{\mathrm{A}}$, the note should just be only on לֵַַרָ, that does occur twice. At 1 Sam 2:15 a circellus has

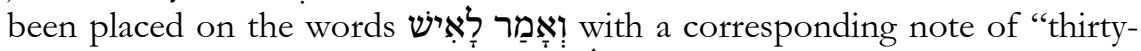

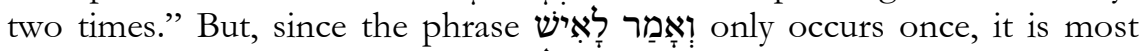
likely that the note refers just to לִָ ְִיש, which does occur thirty-two times.

- Extra notes in the ms. On some occasions one finds extra Mp notes which do not correspond to any word which is in the adjacent line. At Josh 19:25

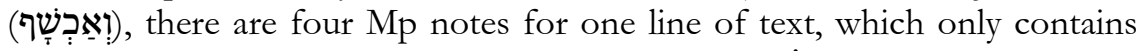
three words in the line. The fourth Mp note of $\dot{\beth}$ does not match any parallel word in either column. At Judg 11:5 (מאָרֵֶץ טוֹב), there is a Mp note of ', which has no associated circellus and which does not match any of the immediate words in its vicinity.

\section{TEXTUAL NOTES CONCERNING THE MM}

The types of textual note concerning the Mm primarily have to do with the placement of the $\mathrm{Mm}$ note. Usually the $\mathrm{Mm}$ notes in $\mathrm{M}^{\mathrm{L}}$ are placed on the upper and lower margins, and usually correspond to the occurrence of lemmas on that particular folio. However there are many occasions when a Mm note occurs on the follow-

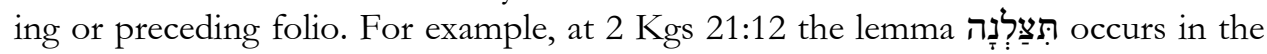
ms. in folio $217 \mathrm{r}$, but the Mm note on this lemma appears on the top right of the

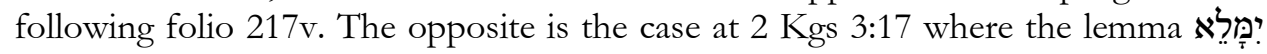
occurs in the ms. in folio $204 \mathrm{r}$, but the Mm note on this lemma appears on the bottom right of the preceding folio $203 \mathrm{v}$.

There are some cases where the same note appear both in the preceding and following folio. Thus the lemma עַד־עֶצט הַיוֹם הַזֶּ (Josh 10:27) occurs in the ms. on folio $127 \mathrm{v}$, but its $\mathrm{Mm}$ note appears once on the preceding page on the bottom left of fol. 127r, and once on the following page on the bottom left of fol. 128r. It is also possible for more than one note to be on the preceding or following folio. In fact,

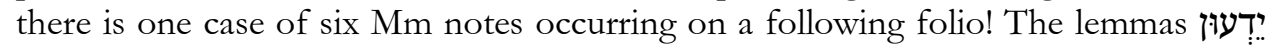

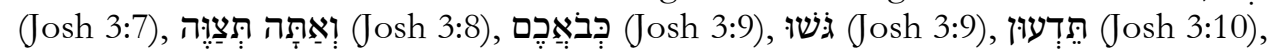
and שְׁני עָשָָׁר (Josh 3:12) all occur in the ms. in folio 122v, but their Mm notes are written on the bottom right of the following folio $123 \mathrm{r}$. 